\title{
Bioprospection and characterization of the amylolytic activity by filamentous fungi from Brazilian Atlantic Forest
}

\author{
Paula Zaghetto de Almeida ${ }^{I}$, Marita Gimenez Pereira ${ }^{2}$, Caio Cesar de Carvalho ${ }^{2}$, Paulo Ricardo Heinen ${ }^{I}$, \\ Luciana Sobrani Ziotti², Josana Maria Messias ${ }^{3}$, João Atilio Jorge ${ }^{2}$ \& \\ Maria de Lourdes Teixeira de Moraes Polizeli ${ }^{2 *}$ \\ ${ }^{1}$ Universidade de São Paulo, Faculdade de Medicina de Ribeirão Preto, Departamento de Bioquímica e Imunologia, \\ Ribeirão Preto, SP, Brazil \\ ${ }^{2}$ Universidade de São Paulo, Faculdade de Filosofia, Ciências e Letras, Departamento de Biologia, Ribeirão Preto, SP, Brazil \\ ${ }^{3}$ Universidade de São Paulo, Faculdade de Filosofia, Ciências e Letras, Departamento de Química, Ribeirão Preto, SP, Brazil \\ *Corresponding author: Maria de Lourdes Teixeira de Moraes Polizeli, e-mail: polizeli@ffclrp.usp.br
}

ALMEIDA, P. Z., PEREIRA, M. G., CARVALHO, C. C., HEINEN, P. R., ZIOTTI, L. S., MESSIAS, J. M., JORGE, J. A., POLIZELI, M. L. T. M. Bioprospection and characterization of the amylolytic activity by filamentous fungi from Brazilian Atlantic Forest. Biota Neotropica. 17(3): e20170337. http://dx.doi.org/10.1590/1676-0611-BN-2017-0337

\begin{abstract}
Filamentous fungi are widely diverse and ubiquitous organisms. Such biodiversity is barely known, making room for a great potential still to be discovered, especially in tropical environments - which are favorable to growth and species variety. Filamentous fungi are extensively applied to the production of industrial enzymes, such as the amylases. This class of enzymes acts in the hydrolysis of starch to glucose or maltooligosaccharides. In this work twenty-five filamentous fungi were isolated from samples of decomposing material collected in the Brazilian Atlantic Forest. The two best amylase producers were identified as Aspergillus brasiliensis and Rhizopus oryzae. Both are mesophilic, they grow well in organic nitrogen-rich media produce great amounts of glucoamylases. The enzymes of $A$. brasiliensis and $R$. oryzae are different, possibly because of their phylogenetical distance. The best amylase production of $A$. brasiliensis occurred during 120 hours with initial $\mathrm{pH}$ of 7.5; it had a better activity in the $\mathrm{pH}$ range of 3.5-5.0 and at $60-75^{\circ} \mathrm{C}$. Both fungal glucoamylase had wide $\mathrm{pH}$ stability (3-8) and were activated by $\mathrm{Mn}^{2+}$. $R$. oryzae best production occurred in 96 hours and at $\mathrm{pH}$ 6.5. Its amylases had a greater activity in the $\mathrm{pH}$ range of 4.0-5.5 and temperature at $50-65^{\circ} \mathrm{C}$. The most significant difference between the enzymes produced by both fungi is the resistance to thermal denaturation: A. brasiliensis glucoamylase had a $\mathrm{T}_{50}$ of 60 minutes at $70^{\circ} \mathrm{C}$. The $R$. oryzae glucoamylase only had a residual activity when incubated at $50^{\circ} \mathrm{C}$ with a $12 \mathrm{~min} \mathrm{~T}_{50}$.
\end{abstract}

Keywords: Amylase, Filamentous fungi, Aspergillus brasiliensis, Rhizopus oryzae, Glucoamylase, Bioprospection

\section{Bioprospecção e caracterização da atividade amilolítica de fungos filamentosos da Mata Atlântica Brasileira}

Resumo: Fungos filamentosos são organismos amplamente diversificados e ubíquos. Esta biodiversidade ainda é pouco caracterizada, desta forma, há um grande potencial a ser descoberto, sobretudo em biomas tropicais, que favorecem o crescimento e diversificação de espécies. Fungos filamentosos são extensivamente utilizados para a produção industrial de enzimas, como as amilases. Esta classe de enzimas atua na hidrólise do amido em glicose ou maltooligossacarídeos. Neste trabalho 25 cepas de fungos filamentosos foram isoladas a partir de amostras de material em decomposição coletados na Mata Atlântica Brasileira. As duas cepas que produziram mais amilases foram identificadas como Aspergillus brasiliensis e Rhizopus oryzae. Ambos os fungos são mesofílicos, crescem bem em meio de cultivo rico em nitrogênio orgânico, e produziram grande quantidade de glucoamilase. As enzimas de A. brasiliensis e R. oryzae possuem características distintas, possivelmente devido à distância filogenética das espécies. A produção de amilase mais expressiva de $A$. brasiliensis ocorreu em 120 horas de cultivo e $\mathrm{pH}$ inicial de 7,5; possui maior atividade em temperaturas entre $60-75^{\circ} \mathrm{C}$ e $\mathrm{pH}$ entre 3,5-5,0. Ambas glucoamilases fúngicas obtiveram ampla estabilidade de $\mathrm{pH}(3-8)$ e foram ativadas por $\mathrm{Mn}^{2+}$. A melhor produção de $R$. oryzae ocorreu em 96 horas de cultivo e pH 6,5. Suas amilases são mais ativas na faixa de $\mathrm{pH}$ de 4,0-5,5 e temperatura entre $50-60^{\circ} \mathrm{C}$. A diferença mais significativa dentre as enzimas produzidas pelos fungos selecionados é a resistência à desnaturação térmica, tendo a glucoamilase de $A$. brasiliensis um $\mathrm{T}_{50}$ de 60 minutos a $70^{\circ} \mathrm{C}$, já a glucoamilase de $R$. oryzae somente obteve atividade residual quando incubada a $50^{\circ} \mathrm{C}$, com um $\mathrm{T}_{50}$ de apenas 12 minutos.

Palavras-Chave: Amilase, Fungos filamentosos, Aspergillus brasiliensis, Rhizopus oryzae, Glucoamilase, Bioprospecção 


\section{Introduction}

Fungi are widely diverse and distributed in all terrestrial ecosystems. They are decomposers, mutualists or pathogens with crucial roles in the cycling of nutrients (Tedersoo et al. 2014). According to Blackwell (2011), it is estimated that there are about 5.1 million species of fungi around the world. Up to the present date, the dictionary of fungi counts fewer than 100,000 species (Kirk et al. 2008).

Fungus diversity is spread along a latitudinal gradient. Therefore, equatorial and tropical forests, such as the Brazilian Atlantic forest, hold a great part of this diversity (Shi et al. 2014; Tedersoo et al. 2014). This forest has one of the most diverse and threatened biotas of the world, which remains with just $11.4 \%$ to $16 \%$ of the original coverage (Ribeiro et al. 2009; Joly et al. 2014).

Filamentous fungi are known as great enzyme producers, like amylases. Starch is the main reserve carbohydrate in plants and the second most abundant carbohydrate in nature. It is present in corn, potato, rice and wheat, what accounts for a great part of the human diet. Starch is enzymatically hydrolyzed to maltose, glucose and oligosaccharide syrup (Vielle \& Zeikus 2001). Amylases are widely applied in industries such as textile, paper and cellulose, detergent, baking and beverage. They account for about $30 \%$ of total enzymes commercialized (Vielle \& Zeikus 2001; Van Der Maarel 2002; Souza \& Magalhães, 2010). Enzymatic hydrolysis is more specific than is chemical hydrolysis and has a theoretical efficiency of $100 \%$ (Ballesteros et al. 2002).

In this research, 25 filamentous fungi present in decaying material from the Brazilian Atlantic forest were isolated. The two strains with bigger secretion of enzymes had the production optimized and the amylases of crude extract were characterized. They showed characteristics with possible industrial application.

\section{Material and Methods}

\section{Isolation of fungi}

The fungi were isolated from decaying materials collected in the Atlantic forest in Peruíbe, SP, Brazil (Table 1). The samples were stored in sterile tubes, diluted in the ration of 1:1000 or 1:10000 and plated in oatmeal agar ( $2 \%$ oatmeal flour, $2 \%$ bacteriological agar, $0.5 \%$ glucose) containing traces of pentabiotic (benzathine benzylpenicillin, procain benzylpenicillin, potassium benzylpenicillin, dihydrostreptomycin sulfate, streptomycin sulfate). The Petri plates were incubated at $30^{\circ} \mathrm{C}$ for seven days. The strains grown were purified through successive streaking.

\subsection{Selection of strains}

The isolated strains were grown in conical tubes containing oatmeal medium. An aqueous suspension of conidia was obtained by scraping the surface of each one of these cultures with $10 \mathrm{~mL}$ distilled water. A volume of $1 \mathrm{~mL}$ of the conidia suspension was inoculated in $25 \mathrm{~mL}$ Adams modified medium (AM) as described by Peixoto et al. (2003) during 72 hours at $30^{\circ} \mathrm{C}$. Then, the cultures were vacuum-filtered and dialyzed overnight in distilled water at $4^{\circ} \mathrm{C}$ for removal of residual reducing sugars. After this process, the amylolytic activity was measured.

\subsection{Enzymatic assay}

Amylolytic activity was determined with 3,5-Dinitrosalicylic acid (DNS) (Miller 1959). The assay was composed of $50 \mu \mathrm{L}$ crude extract and $50 \mu \mathrm{L}$ $1 \%$ soluble starch in $50 \mathrm{mM}$ sodium citrate buffer, $\mathrm{pH}$ 5.5. The mixture was incubated at $60^{\circ} \mathrm{C}$ for $5 \mathrm{~min}$, interrupted by the addition of $100 \mu \mathrm{L}$ DNS reagent, and boiled for 5 minutes. After cooling, $1 \mathrm{~mL}$ distilled water was added and the assay was read at $540 \mathrm{~nm}$ in SpectraMax Plus 384 Microplate Reader. The blank was consisted the enzyme inactivated by DNS prior to the addition of the substrate. One unit of enzyme activity was defined as that catalyzing the conversion of $1 \mu \mathrm{mol}$ glucose, per minute, in the assay conditions.

\subsection{Optimization of culture}

The cultures were carried out in $125 \mathrm{~mL}$ Erlenmeyer flasks containing $25 \mathrm{~mL}$ of one of the following liquid media: AM (Adams 1990, Peixoto et al. 2003); Khanna (Khanna et al. 1995), Segato Rizzatti (SR, Rizzatti et al. 2001) or Vogel (Vogel 1964). The $\mathrm{pH}$ of the medium was adjusted to 6.5 and it was supplemented with $1 \%$ soluble starch, as carbon source. A volume of $10^{5}$ spores per $\mathrm{mL}$ of culture medium was inoculated and the incubation occurred in bacteriological incubator (static condition) or shaker $(100 \mathrm{rpm})$ for 3 days, at $30^{\circ} \mathrm{C}$.

In order to determine the best temperature for fungal growth, cultures were held at $25,30,35$ and $40^{\circ} \mathrm{C}$ during 72 hours in the culture medium previously selected (AM and SR). In order to determine the effect of the initial $\mathrm{pH}$ in the enzymatic production, a $\mathrm{pH}$ range of 6.5 to 8.5 was tested for Aspergillus brasiliensis and 5.5 to 7.5 for Rhizopus oryzae. Time course was performed up to 144 hours to select the time of higher enzymatic secretion.

Table 1. Georeferencing means of isolated fungi and amylase activity

\begin{tabular}{|c|c|c|c|c|c|c|}
\hline $\begin{array}{c}\text { Collected } \\
\text { material }\end{array}$ & $\begin{array}{c}\text { Temperature } \\
\left({ }^{\circ} \mathrm{C}\right)\end{array}$ & $\begin{array}{c}\text { GPS precision } \\
\text { (m) }\end{array}$ & Altitude (m) & Latitude & Longitude & Isolated fungi (Amylase U/mL) \\
\hline Lichen & 30 & 15 & 11 & $\mathrm{~S}-24^{\circ} 22.405^{\prime}$ & $\mathrm{H} 047^{\circ} 03.951^{\prime}$ & $1 / 9 \mathrm{~A}(0) ; 1 \mathrm{~A}(0) ; 1 \mathrm{~B}(0) ; 1 \mathrm{C}(4.4) ; 1 \mathrm{D}(0.3)$ \\
\hline Flower & 29 & 15 & 11 & $\mathrm{~S}-24^{\circ} 22.405^{\prime}$ & $\mathrm{H} 047^{\circ} 03.951^{\prime}$ & $2 \mathrm{~A}(0.2) ; 2 \mathrm{~B}(0.2)$ \\
\hline Branch & 30 & 15 & 11 & $\mathrm{~S}-24^{\circ} 22.405^{\prime}$ & $\mathrm{H} 047^{\circ} 03.951^{\prime}$ & $3 \mathrm{~A}(0.5)$ \\
\hline Green Leaf & 26 & 11 & 34 & $\mathrm{~S}-24^{\circ} 26.462^{\prime}$ & $\mathrm{H} 047^{\circ} 04.050^{\prime}$ & $5 \mathrm{~A}(0.4)$ \\
\hline Bracken & 26 & 16 & 34 & $\mathrm{~S}-24^{\circ} 26.462^{\prime}$ & $\mathrm{H} 047^{\circ} 04.050^{\prime}$ & $6 \mathrm{~A}(0.4) ; 6 \mathrm{~B}(3.5)$ \\
\hline Lichen & 26 & 16 & 34 & $\mathrm{~S}-24^{\circ} 26.462^{\prime}$ & $\mathrm{H} 047^{\circ} 04.050^{\prime}$ & $7 \mathrm{~A}(0.5)$ \\
\hline Leaf litter & 26 & 16 & 34 & $\mathrm{~S}-24^{\circ} 26.462^{\prime}$ & $\mathrm{H} 047^{\circ} 04.050^{\prime}$ & $8 \mathrm{~A}(4.2) ; 8 \mathrm{~B}(0.5) ; 8 \mathrm{C}(0.3)$ \\
\hline Leaf & 26 & 11 & 2 & $\mathrm{~S}-24^{\circ} 24.462^{\prime}$ & $\mathrm{H} 047^{\circ} 04.050^{\prime}$ & $9 \mathrm{~A}(0.5) ; 9 \mathrm{~B}(0)$ \\
\hline Lichen stone & 29 & 9 & 2 & $\mathrm{~S}-24^{\circ} 26.054^{\prime}$ & $\mathrm{H} 047^{\circ} 03.437^{\prime}$ & $10 \mathrm{~A}(0) ; 10 \mathrm{~B}(0.1)$ \\
\hline Sand & 29 & 10 & 0 & $\mathrm{~S}-24^{\circ} 26.038^{\prime}$ & $\mathrm{H} 047^{\circ} 03.450^{\prime}$ & $11 \mathrm{~A}(0)$ \\
\hline Fruit & 29 & 9 & 34 & $\mathrm{~S}-24^{\circ} 25.987^{\prime}$ & $\mathrm{H} 047^{\circ} 03.440^{\prime}$ & $13 \mathrm{~A}(0)$ \\
\hline Mushroom & 29 & 14 & 5 & $\mathrm{~S}-24^{\circ} 25.462^{\prime}$ & $\mathrm{H} 047^{\circ} 03.440^{\prime}$ & $14 \mathrm{~A}(0.5) ; 14 \mathrm{~B}(0.7) ; 14 \mathrm{C}(0)$ \\
\hline Atemoya & 29 & 17 & 25 & $\mathrm{~S}-24^{\circ} 25.916^{\prime}$ & $\mathrm{H} 047^{\circ} 03.445^{\prime}$ & $15 \mathrm{~A}(0.3)$ \\
\hline
\end{tabular}




\subsection{Characterization of the crude extract}

In order to determine the $\mathrm{pH}$ stability, the crude extract was incubated in McIlvaine buffer between 2.5 and 8.0 during 24 hours at $25^{\circ} \mathrm{C}$ (McIlvaine 1921). The resistance to thermal denaturation was determined at 50,60 and $70{ }^{\circ} \mathrm{C}$ during 10 to 300 minutes.

In order to estimate the most favorable temperature zone and $\mathrm{pH}$ for enzymatic activity, an experimental design $2^{2}$ was proceeded with three central point repetitions at $\mathrm{p}<0.5 \%$. The results were analyzed with the Statistica 12 software. The points were composed of the variation of $\mathrm{pH}$ in sodium citrate buffer $50 \mathrm{mM}$, range 3.5 to 7.5 , and the temperature in a range of 40 to $70^{\circ} \mathrm{C}$.

Several carbon sources (starch, wheat bran, glucose, maltose, barley bagasse, ground corn and oatmeal flour), at $1 \%$ concentration, were added to culture media of both fungi aiming to determine the type of amylase synthetized in optimal conditions of the microorganism development. After incubation, the samples were collected, dialyzed and incubated with $1 \%$ starch in sodium citrate buffer, for 20 minutes. The enzymatic assays were stopped by boiling. The end-products of the enzymatic assays were applied in a Thin-Layer Chromatography (TLC) and a solution of $1 \mathrm{mg} / \mathrm{mL}$ glucose, maltose, maltotriose, maltotetraose, and maltopentose was carried as control. The chromatography was developed in a solution of n-butanol, ethanol and distilled water $(5: 3: 2)$. After the plates were developed and dried, they were sprayed with a solution containing $18 \mathrm{~mL}$ methanol, $2 \mathrm{~mL}$ sulfuric acid, and $0.04 \mathrm{~g}$ orcinol, and it was revealed at $100^{\circ} \mathrm{C}$ until the spots came clear.

The following compounds were added in the enzymatic assays at concentrations of 2 and $5 \mathrm{mM}$ to determine the effect on the activity: $\mathrm{NH}_{4} \mathrm{~F}$, $\mathrm{NaH}_{2} \mathrm{PO}_{4}, \mathrm{ZnCl}_{2}, \mathrm{AlCl}_{3} \cdot 6 \mathrm{H}_{2} \mathrm{O}, \mathrm{AgNO}_{3}, \mathrm{KH}_{2} \mathrm{PO}_{4}, \mathrm{CuSO}_{4} .5 \mathrm{H}_{2} \mathrm{O}, \mathrm{BaCl}, \mathrm{NH}_{4} \mathrm{Cl}$, $\mathrm{CoCl}_{2} \cdot 6 \mathrm{H}_{2} \mathrm{O}, \mathrm{MgCl}_{2} \cdot 6 \mathrm{H}_{2} \mathrm{O}, \mathrm{Zn}\left(\mathrm{NO}_{3}\right)_{2} \cdot 6 \mathrm{H}_{2} \mathrm{O}, \mathrm{KCl}, \mathrm{Pb}\left(\mathrm{C}_{2} \mathrm{H}_{3} \mathrm{O}_{2}\right)_{2} \cdot 3 \mathrm{H}_{2} \mathrm{O}, \mathrm{NaBr}$, $\mathrm{CaCl}, \mathrm{NaCl}, \mathrm{MnCl}_{2} \cdot 4 \mathrm{H}_{2} \mathrm{O}, \beta$-mercaptoethanol and EDTA.

\subsection{Fungi identification and deposit}

The fungi $6 \mathrm{~B}$ and $8 \mathrm{~A}$ were identified using the regions of ITS1-ITS4 (Forward 5'-TCCGTAGGTGAACCTTGCGG-3' - Reverse 5'-TCCTCCGCTTATTGATATGC-3'), Calmodulin (Forward 5'-GCCGACTCTTTGACYGARGAR-3' - Reverse 5' -TTTYTGCATCATRAGYTGGAC-3') and $\beta$-tubulin (Forward 5'-GGTAACCAAATGGTGCTGCTTTC-3' - Reverse 5'-ACCCTCAGTGTAGTGACCCTTGGC-3') (White et al. 1990, Glass \& Donaldson 1995, Balajee et al. 2009). The DNA extraction occurred according to Maki et al (2001). The sequencing was carried out at the blood center of Ribeirão Preto-SP. The sequences were aligned on BioEdit and blasted on GenBank database. The strains identified were added to the Filamentous Fungi Collection from the Faculdade de Filosofia, Ciências e Letras de Ribeirão Preto (FFCLRP-USP), and catalogued as CFF124 to $A$. brasiliensis and CFF 132 to $R$. oryzae. The unidentified fungi were cryopreserved for future access.

\subsection{Phylogenetic analysis}

The Phylogenetic analysis with Rhizopus oryzae and Aspergillus brasiliensis was based on the regions of Internal Transcribed Spacer (ITS) 1 and 4. A multiple alignment of sequences was obtained with the MUSCLE 3.6 software (Edgar 2004). Phylogenetic and molecular evolutionary analyses were conducted using MEGA version 6 (Tamura et al. 2013). The phylogenetic trees were based on the Maximum Likehood using the Neighbor-Joining method with 500 robustness non-parametric bootstrap replicates. The similarity rate between the sequences was shown in percentage considering the number of conserved bases and the total number of aligned bases.

\section{Results}

\section{Selection and identification}

Twenty-five strains of filamentous fungi were isolated from samples of organic material in decomposition (Table 1). The strains were cultivated for 3 days in AM liquid medium. The amylolytic activities of the crude extracts were measured and are expressed on Table 1. Two strains stood out: the fungus $6 \mathrm{~B}(3.5 \mathrm{U} / \mathrm{mL})$ and the fungus $8 \mathrm{~A}(4.2 \mathrm{U} / \mathrm{mL})$.

The regions ITS 1-4 were amplified and sequenced for the identification of fungi (Table 2). The fungus 8A was identified as Rhizopus oryzae Went \& Prinsen Geerligs. The fungus 6B showed a great similarity to the fungus Aspergillus brasiliensis Varga, Frisvad \& Samson and Aspergillus niger van Tiegh. Hence, the amplification of the fragment of $\beta$-tubulin and calmodulin genes was performed, concluding the identification as Aspergillus brasiliensis.

\subsection{Optimization of culture}

The fungi selected were cultured in Khanna, AM, SR and Vogel media for 3 days, at $30^{\circ} \mathrm{C}$, either in stirring at $100 \mathrm{rpm}$ or in static condition, with initial $\mathrm{pH}$ adjusted to 6.5 . The inoculum was composed of $10^{5}$ spores per $\mathrm{mL}$ of culture medium. A. brasiliensis had a greater secretion in the SR medium under static fermentation, which saves more energy in comparison with the agitation condition (Figure 1). The SR medium contains yeast extract $(0.45 \%)$ as the main source of nitrogen and it was the only medium tested with peptone $(0.02 \%)$. The salt compositions of the culture medium are monobasic potassium phosphate in low concentration $(0.015 \%), 0.012 \%$ magnesium sulfate heptahydrate and $0.05 \%$ monobasic ammonium phosphate. The latter can be also considered as a source of inorganic nitrogen.

$R$. oryzae had the best secretion of amylases in AM medium under agitation. AM medium has the biggest amount of yeast extract between the media tested $(0.8 \%)$. In the Vogel medium, its activity was very low, suggesting a low assimilation of inorganic nitrogen. Besides carbon and nitrogen sources, the AM medium is composed by only two salts: monobasic potassium phosphate $(0.3 \%)$ and magnesium sulfate heptahydrate $(0.05 \%)$, both in a much higher concentration than the SR medium.

The fungi were grown in several temperatures in the previously standardized medium conditions for 3 days. The extracellular amylolytic activity was greater at $30^{\circ} \mathrm{C}$ for both fungi, suggesting that both are to be considered as mesophilic (Figure 2A).

In order to determine the ideal initial $\mathrm{pH}$, the culture media were adjusted in the range $6.5-8.5$ to the fungus $A$. brasiliensis, and in the range of 5.5 to 7.5 for $R$. oryzae. The initial $\mathrm{pH}$ of 7.5 favored the production

Table 2. Homologies found with the nucleotide blast tool from NCBI (National Center for Biotechnology Information) to the fungi 6B and 8A

\begin{tabular}{|c|c|c|c|c|c|}
\hline Fungi & Sequence & Homology & Score & Valor E & Identity (\%) \\
\hline \multirow{3}{*}{$6 B$} & ITS 1-4 & $\begin{array}{c}\text { Aspergillus brasiliensis/ } \\
\text { Aspergillus niger }\end{array}$ & $894 / 893$ & $0.0 / 0.0$ & $100 / 100$ \\
\hline & $\beta$-tubulin & Aspergillus brasiliensis & 819 & 0.0 & 100 \\
\hline & Calmodulin & Aspergillus brasiliensis & 1201 & 0.0 & 100 \\
\hline $\mathbf{8 A}$ & ITS $1-4$ & Rhizopus oryzae & 791 & 0.0 & 100 \\
\hline
\end{tabular}




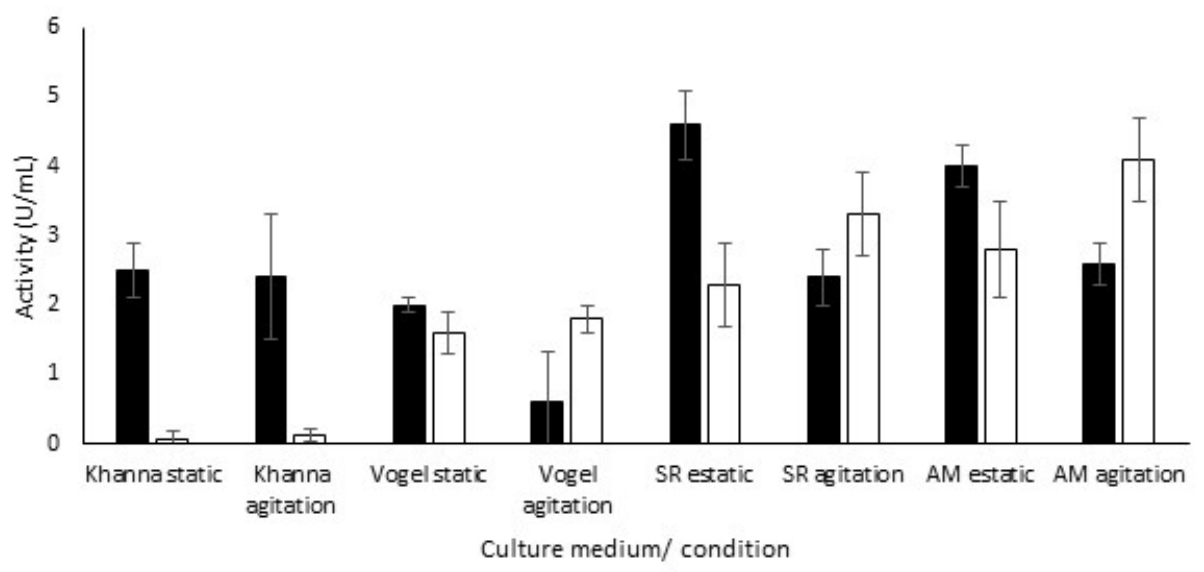

Figure 1. Production of amylase in several culture media, under static and agitation conditions. Symbols: (ロ) A. brasiliensis; ( $\square)$ R. oryzae.
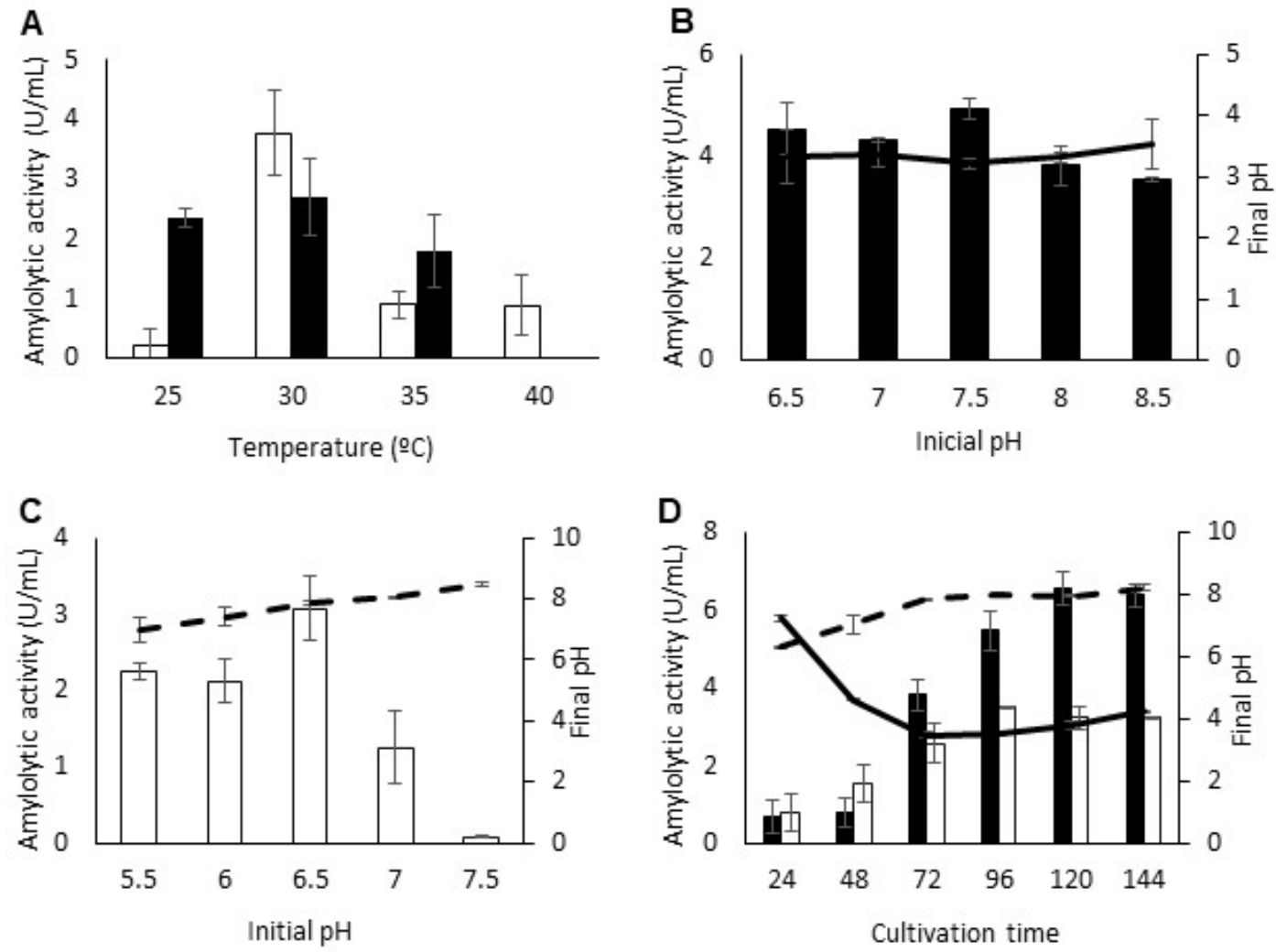

Figure 2. Determination of the effect of temperature (A), $\mathrm{pH}(\mathrm{B}, \mathrm{C})$ and time of culture on amylase activity $(\mathrm{U} / \mathrm{mL})$ of A. brasiliensis $(\square)$, and R. oryzae ( $\square)$. Final $\mathrm{pH}$ of $A$. brasiliensis (-); R. oryzae (- -).

of amylases by $A$. brasiliensis (Figure $2 \mathrm{~B}$ ). The final $\mathrm{pH}$ in all conditions tested was much lower than the initial one (around 3.5). In contrast, the best initial $\mathrm{pH}$ to $R$. oryzae was 6.5 (Figure $2 \mathrm{C}$ ). The final $\mathrm{pH}$ in every condition was higher than was it in the initial one (about 8.0).

Time-course of amylase production was carried until 144 hours (Figure 2D). The period of 120 hours had the greater amylolytic secretion to $A$. brasiliensis. It was also noted that the $\mathrm{pH}$ of the culture medium began decreasing on the second day and stabilized after 72 hours. On the other hand, the culture of 96 hours was more favorable to $\mathrm{R}$. oryzae. The $\mathrm{pH}$ of the culture medium began increasing on the second day and stabilized after 72 hours.

\subsection{Optimum $\mathrm{pH}$ and temperature}

An experimental design was performed to determine the optimum $\mathrm{pH}$ and temperature for the enzymatic hydrolysis according the points in Table 3. The experimental design was composed of 11 assays with 3 repetitions at the central point. According to the results, the enzymatic activity of the crude extract of $A$. brasiliensis was determined by the following equation:

Activity $(\mathrm{U} / \mathrm{mL})=5.55-1.99 . \mathrm{pH}-1 .\left(\mathrm{T}^{\circ} \mathrm{C} \cdot \mathrm{pH}\right)-1.42 .\left(\mathrm{T}^{\circ} \mathrm{C}\right)^{2}-1.14$. $(\mathrm{pH})^{2}$ 
The surface (Figure $3 \mathrm{~A}$ ) plot shows that the ideal assay temperature was in the range of $60-75^{\circ} \mathrm{C}$, and the $\mathrm{pH}$ of $3.5-5$. Replacing the values correspondent to $70^{\circ} \mathrm{C}(0.943)$ and $\mathrm{pH} 4(-0.977)$, the activity of $6 \mathrm{U} / \mathrm{mL}$ was obtained. An assay in triplicate was carried out in the same parameters and an activity of 6.7 was obtained with a standard variation of \pm 0.7 , as expected to the model, with an $\mathrm{r}^{2}$ of 0.96 and a calculated $\mathrm{F} 18.2$ times higher than the tabulated F.

The enzymatic activity of the crude extract of $R$. oryzae can be determined by the following equation:

Activity $(\mathrm{U} / \mathrm{mL})=2.52-0.68 \cdot \mathrm{pH}-0.96 .\left(\mathrm{T}^{\circ} \mathrm{C}\right)^{2}-0.68 .(\mathrm{pH})^{2}$

According to the surface plot (Figure 3B), the ideal assay temperature was in the range of $50-65^{\circ} \mathrm{C}$ and the $\mathrm{pH}$ of $4 \cdot 0-5.5$. Replacing the values of $60^{\circ} \mathrm{C}(0)$ and $\mathrm{pH} 4.0(-0.977), 2.54 \mathrm{U} / \mathrm{mL}$ was obtained. An assay in the same conditions obtained $2.94 \pm 0.58 \mathrm{U} / \mathrm{mL}$, as expected to the model, with an $\mathrm{r}^{2}$ of 0.9 and a calculated F 5.9 times higher than the tabulated F.

\subsection{Stability and effect of compounds}

The crude extracts were incubated in McIlvaine buffers for 24 hours (Figure $4 \mathrm{~A}$ ) at $25^{\circ} \mathrm{C}$. The amylase of $A$. brasiliensis kept the activity above $90 \%$ in the range of $\mathrm{pH} 3.0-6.5$ and above $88 \%$ in the range of $\mathrm{pH}$

Table 3. Points used at the experimental design for the crude extract of $A$. brasiliensis and R. oryzae

\begin{tabular}{lccccc}
\hline & $\mathbf{- 1 . 4 1}$ & $\mathbf{- 1}$ & $\mathbf{0}$ & $\boldsymbol{1}$ & $+\mathbf{1 . 4 1}$ \\
\hline $\mathbf{p H}$ & 3.5 & 4.09 & 5.5 & 6.91 & 7.5 \\
Temperature & 40 & 45.82 & 60 & 74.18 & 80 \\
\hline
\end{tabular}

A
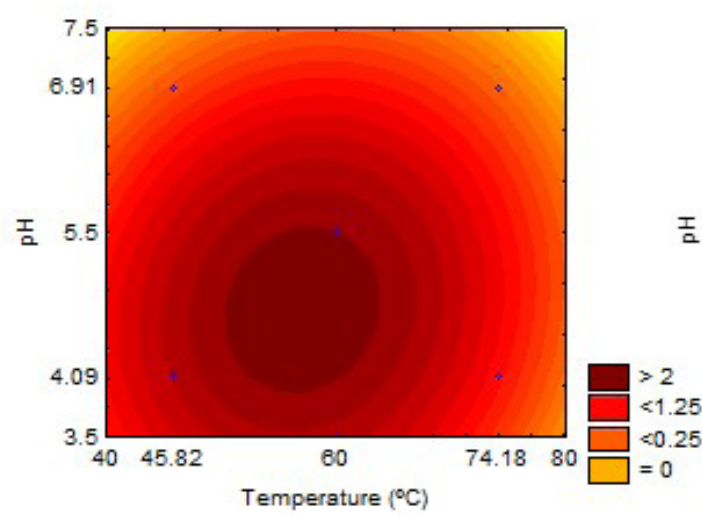

B

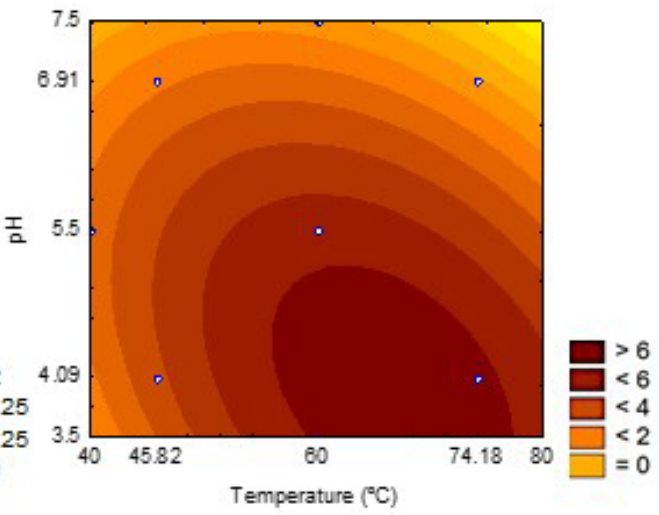

Figure 3. Zone of optimum pH and temperature to (A) A. brasiliensis; (B) R. oryzae.

7.0-8.0. The amylase of $R$. oryzae kept $100 \%$ of the activity in the range of $\mathrm{pH} 3.5-8.0$. At $\mathrm{pH} 3.0$, it kept $91 \%$ of its activity and $75 \%$ at $\mathrm{pH} 2.5$.

The thermal denaturation of amylases of both fungi was analyzed at several times and temperatures (Figure 4B). Amylases of $A$. brasiliensis were completely stable at $50^{\circ} \mathrm{C}$, for 120 minutes. The enzyme was completely stable at $60^{\circ} \mathrm{C}$, for 100 minutes. However, at $70^{\circ} \mathrm{C}$ the half-life was 32 minutes. $R$. oryzae amylases, among all assayed conditions, just had residual activity after exposure at $50^{\circ} \mathrm{C}$, with a half-life of 12 minutes.

The influence of several compounds upon the amylolytic activity was tested (Table 4). The $\mathrm{Al}^{3+}$ ions had little influence upon A. brasiliensis but, in contrast, at $5 \mathrm{mM}$, it completely inhibited the $R$. oryzae amylase. $\mathrm{Ag}^{2+}$ decreased the amylase of both fungi extracts, but had a greater effect over $R$. oryzae, with no residual activity at the highest concentration. The amylase activity of $R$. oryzae was $55 \%$ inhibited with $5 \mathrm{mM} \mathrm{Cu}^{2+}$ but increased $9 \%$ in $A$. brasiliensis. The $2 \mathrm{mM} \mathrm{Ba}^{2+}$ decreased the activity in A. brasiliensis and a slight increase (7\%) was observed with $5 \mathrm{mM}$ of this compound; the opposite happened with $R$. oryzae, which was activated at $2 \mathrm{mM}$ and inhibited at $5 \mathrm{mM}$. On the other hand, $\mathrm{Co}^{2+}$ ions had little effect over $A$. brasiliensis, but decreased $42 \%$ at $5 \mathrm{mM}$ in $R$. oryzae. Both extracts were not affected by $\mathrm{Pb}^{2+}$. The stronger enzymatic activation was obtained with $5 \mathrm{mM} \mathrm{Mn}^{2+}$ for $A$. brasiliensis and at $2 \mathrm{mM}$ for $R$. oryzae. The glucoamylases of both extracts were not considerably influenced by $\beta$-mercaptoethanol and EDTA.

\subsection{Hydrolysis products of amylase on starch revealed by TLC}

Amylases produced by both fungi in culture media supplemented with several carbon sources (1\% starch; wheat bran; maltose; glucose; barley bagasse; ground corn and oatmeal flour) were assayed with starch and the
A

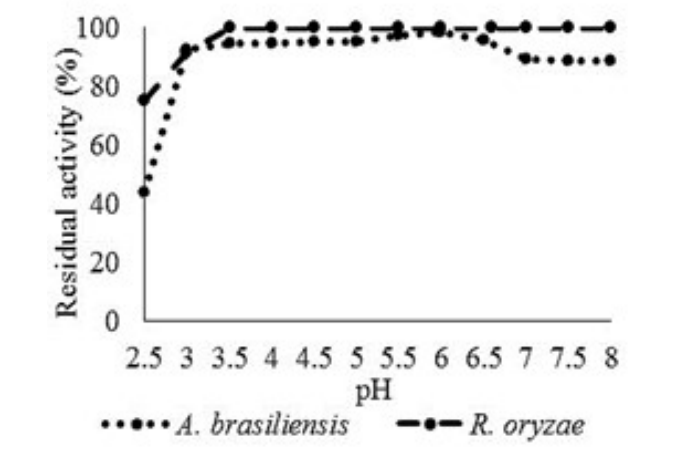

B

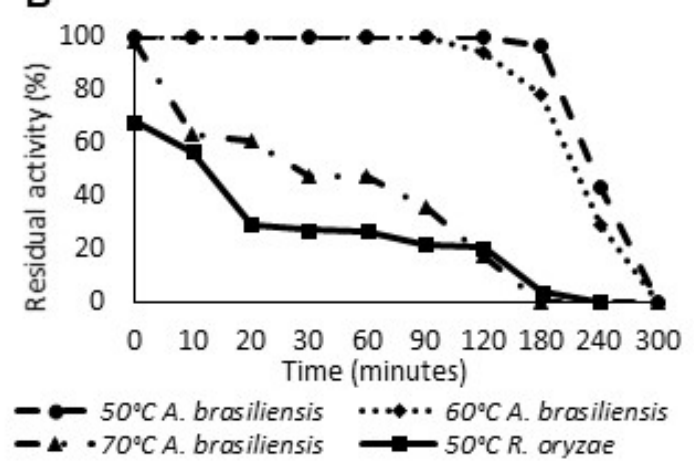

Figure 4. Stability of glucoamylases to $\mathrm{pH}$, after 24 hours, at $25^{\circ} \mathrm{C}(\mathrm{A})$ and thermostability in optimal conditions of enzymatic assay (B) of $A$. brasiliensis and $R$. oryzae. 
Table 4. Effect of compounds at enzymatic activity of A. brasiliensis and $R$. oryzae.

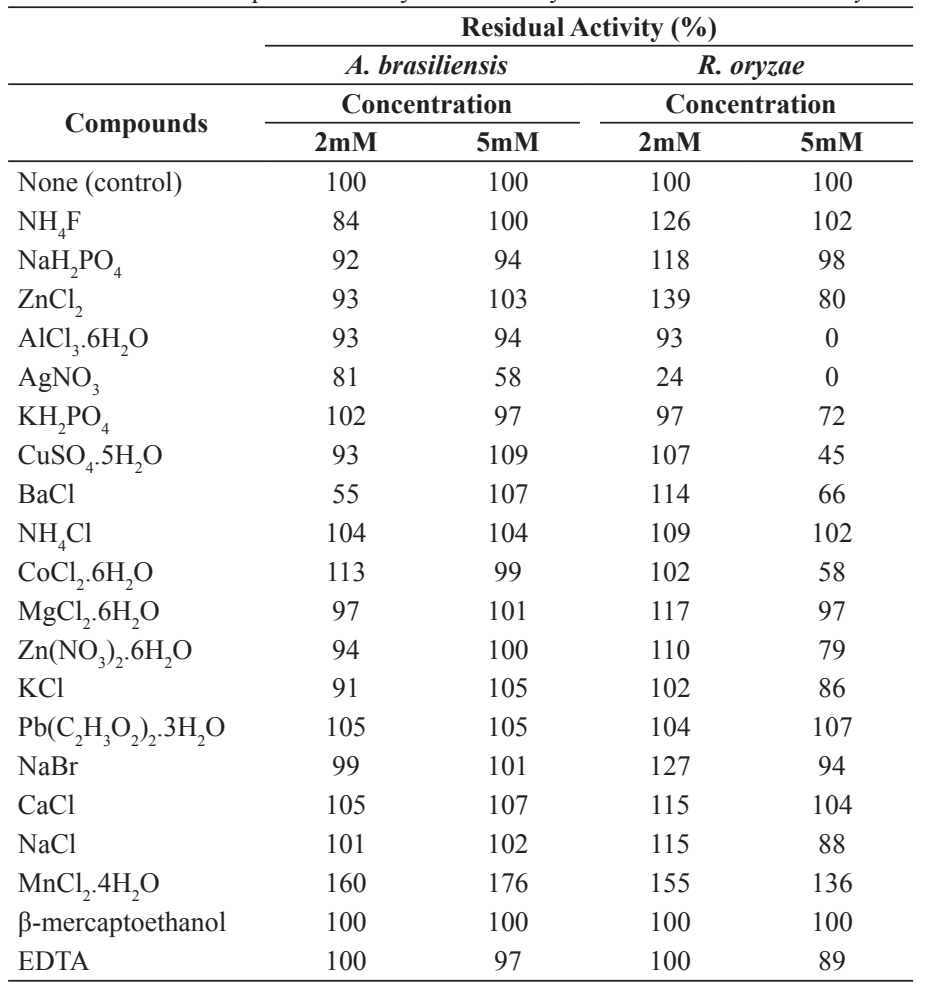

$100 \%$ is equivalent to $5.9 \mathrm{U} / \mathrm{mL}$ to $A$. brasiliensis and $3.9 \mathrm{U} / \mathrm{mL}$ to $R$. oryzae end-products were applied in TLC. The crude extract of A. brasiliensis in all sources enabled a great release of glucose and a small amount of oligosaccharides during the hydrolysis (Figure 5A), signaling for a higher secretion of glucoamylase. There was the production of glucoamylases even in the culture with glucose as an only carbon source, suggesting that it is a constitutive enzyme. The fungus $R$. oryzae also secreted more glucoamylase in all media, but there was the release of some more oligosaccharides, in small quantities, suggesting also the presence of $\alpha$-amylases (Figure 5B). The glucoamylase of $R$. oryzae is also constitutive.

\subsection{Phylogenetic analysis}

The phylogenetic comparison of species close to $R$. oryzae and A. brasiliensis was based on the regions of ITS 1-2 (Internal Transcribed Spacer). The sequences were obtained on GenBank and aligned with MUSCLE 3.6. From the alignment, an unrooted dendrogram that shows the proximity of species was built (Figure 6 ). The analysis showed similarity between the sequences of $A$. nidulans (Eidam) G. Winter and $A$. fumigatus Fersen of $64.5 \% ; 69.8 \%$ between $A$. brasiliensis and A. awamori; $71.1 \%$ between A. oryzae (Ahlb.) Cohn and A. flavus Link. The high rate of similarity between the species of Aspergillus can be observed with Castrillo et al. (2012), where $A$. brasiliensis and A. awamori belong to the same clade, and with Geiser et al. (2000), who demonstrate that $A$. oryzae and A. flavus form a paraphyletic group.

$R$. oryzae and $R$. delemar Boidin ex Wehmer \& Hanzawa have a high rate of similarity $(72.9 \%)$ and constitute a monophyletic group. $R$. niveus M. Yamaz. is closer to $R$. oryzae and $R$. delemar, with a high bootstrap value (100). Between the fungi studied, Rhizopus microsporus var.
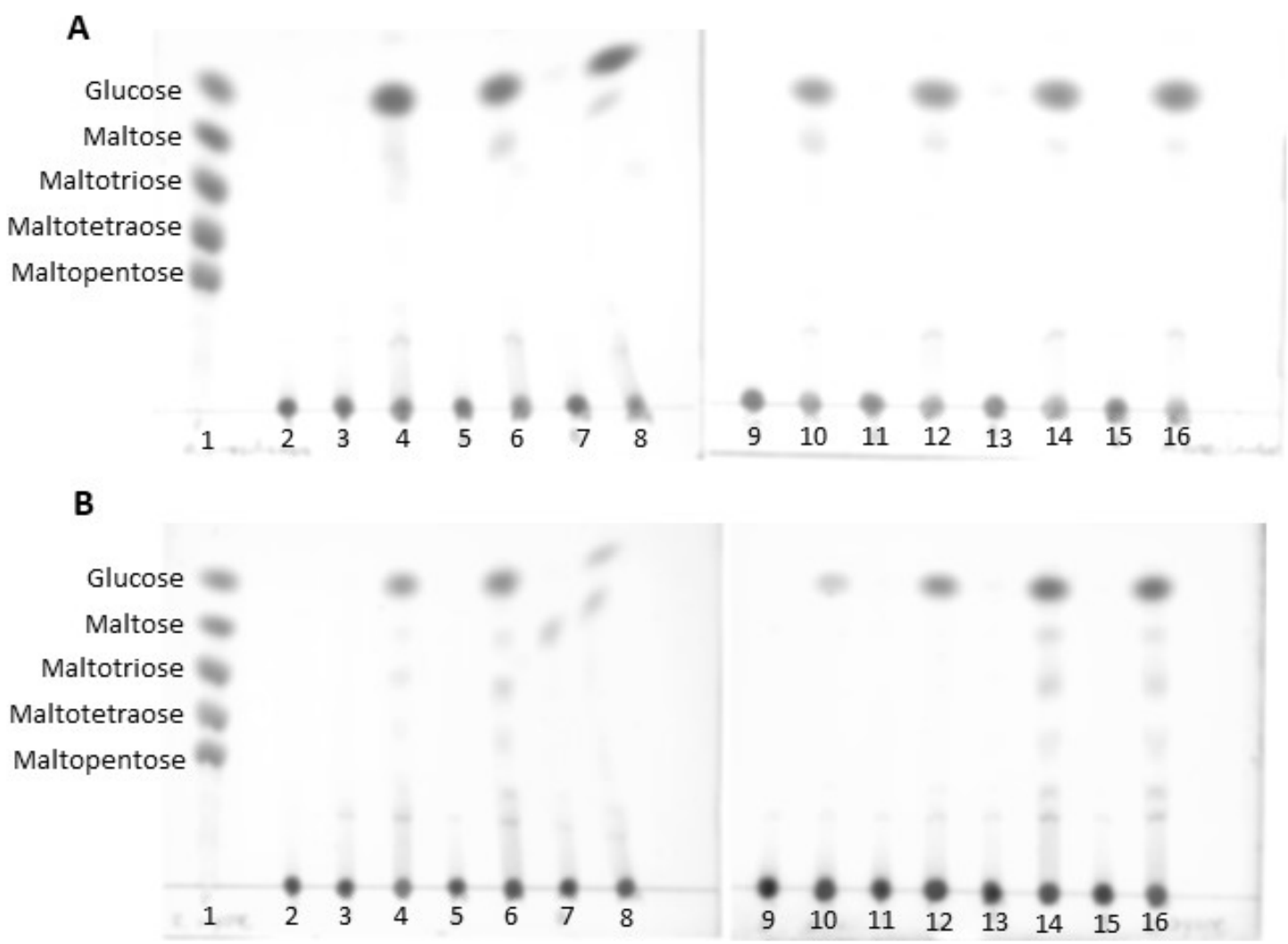

Figure 5. Hydrolysis products of A. brasiliensis (A) and R. oryzae (B) in culture with diverse carbon sources. The samples were applied in the following order: 1- controls; 2-substrate (1\% starch); 3- crude extract of the culture with starch; 4- hydrolysis product of assay with starch extract; 5- wheat bran culture; 6- hydrolysis wheat bran extract; 7-maltose culture; 8- hydrolysis maltose extract; 9- glucose culture; 10- hydrolysis glucose extract; 11- barley bagasse culture; 12- hydrolysis barley bagasse extract; 13- ground corn culture; 14- hydrolysis ground corn extract; 15- oatmeal flour culture; 16- hydrolysis oatmeal flour extract. 


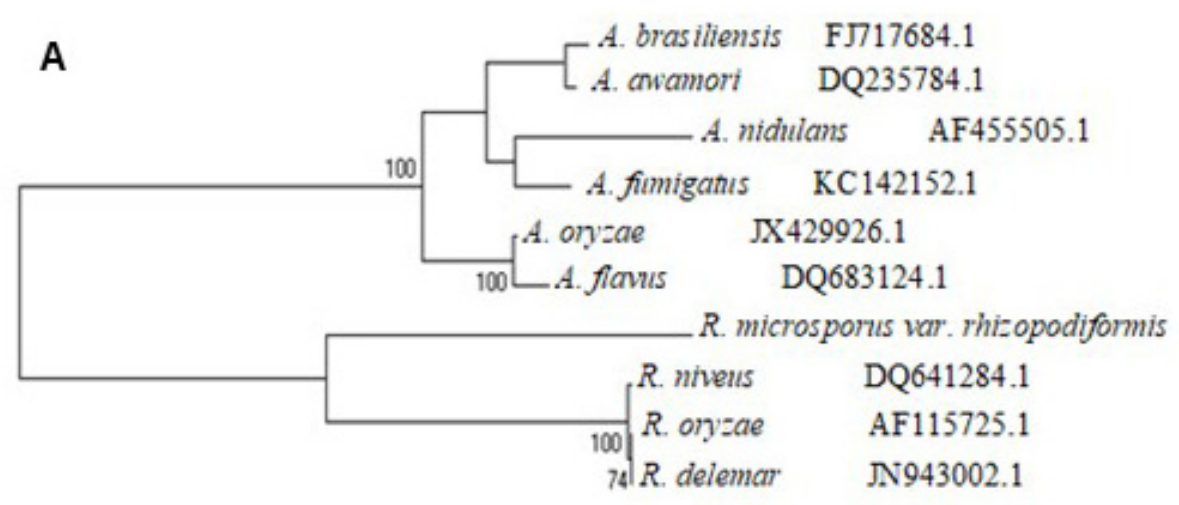

AF115721.1
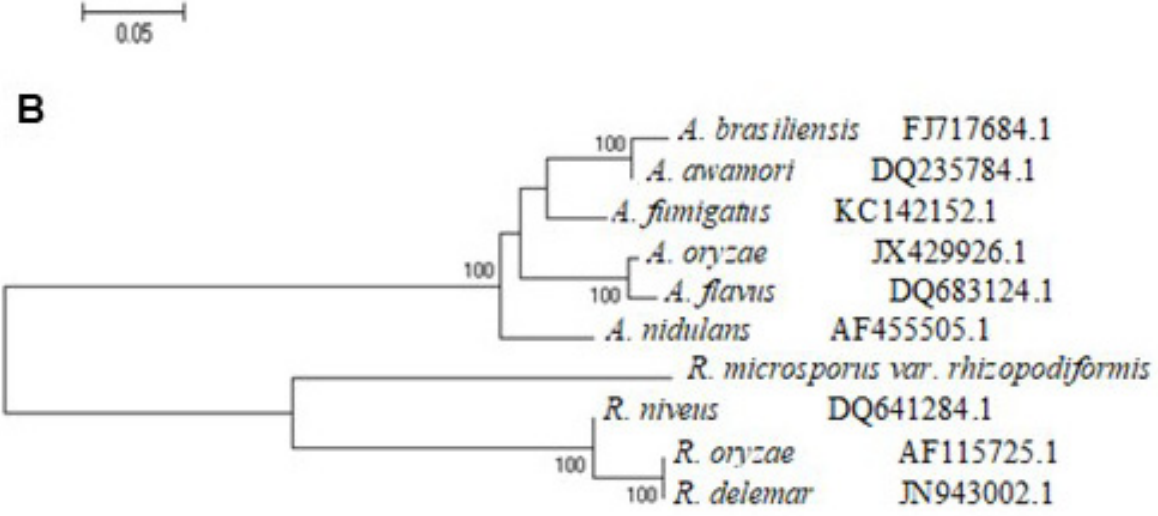

AF115721.1

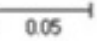

Figure 6: Molecular Phylogenetic analysis (A) by Maximum Likelihood method. The evolutionary history was inferred by using the Maximum Likelihood method based on the Tamura et al. (2013) model. The tree with the highest log likelihood (-2874.0908) is shown. The numbers show the bootstrap value analysis of 500 repetitions and the percentage higher than $70 \%$ of trees in which the associated taxa clustered together is shown next to the branches. The tree is drawn to scale, with branch lengths measured in the number of substitutions per site. The analysis involved 10 nucleotide sequences. There was a total of 776 positions in the final dataset. Evolutionary analyses were conducted in MEGA6. The species names are followed by the GenBank accession number.

(B) by Neighbor-Joining method. The optimal tree with the sum of branch length $=1.00924206$ is shown. The percentage of replicate trees in which the associated taxa is clustered together in the bootstrap test (500 replicates) with the percentage higher than $70 \%$ are shown next to the branches. The tree is drawn to scale, with branch lengths in the same units as those of the evolutionary distances used to infer the phylogenetic tree. The evolutionary distances were computed using the Tajima \& Nei (1984) method and are in the units of the number of base substitutions per site. The rate variation among sites was modeled with a gamma distribution (shape parameter $=2$ ). The analysis involved 10 nucleotide sequences. All ambiguous positions were removed for each sequence pair. There was a total of 776 positions in the final dataset. Evolutionary analyses were conducted in MEGA6. The species names are followed by the GenBank accession number.

rhizopodiformis (Cohn) Schipper \& Stalpers was the most singular of the species, forming an isolated taxon from other fungi of the genera; it also has the lowest rate of similarity ( $49.6 \%$ if compared to $R$. delemar). However, $R$. rhizopodiformis has the necessary apomorphy to be classified close to other Rhizopus. Liou et al. (2007) had similar results when they showed linages of $R$. rhizopodiformis among the main glucoamylase-producing species, what demonstrates the need for more information on this species.

\section{Discussion}

According to Domsch et al. (2007), the fungus distribution is related with the weather, soil, vegetation and the kind of organic matter. Fungi of the genera Aspergillus and Rhizopus are frequently isolated from the Atlantic forest biome (Costa et al. 2012, Schoenlein-Crusius et al. 2006, Tauk Tornisielo et al. 2005, Schoenlein-Crusius \& Milanez 1998). The isolation methodology was not intended to recover a maximum number of species, but strains that were easily cultivated in laboratory conditions and prospective amylase producers.

The amylases have several applications in industry, and each of these bioprocesses requires enzymes with diverse characteristics of $\mathrm{pH}$, temperature and stability. The importance of bioprospection lies in the discovery of novel enzymes, with unique features, that can contribute to a more efficient process (Dhali et al. 2016, Singh et al. 2014).

Coutinho \& Reilly (1997) divided the glucoamylases following their evolutionary history. Fungi of Aspergillus genera are part of the most derivative group of glucoamylases, with a high efficient design. They have a well-developed starch-binding domain and a longer linker region. Fungi from the genera Rhizopus are part of a group with a more primitive glucoamylase structure, which reflects in its efficiency and stability.

The time-course of amylase production showed distinct characteristics of $A$. brasiliensis and $R$. oryzae. The $\mathrm{pH}$ of crude extract differed due to the production of secondary metabolites, probably the production of glycolic and citric acid by $A$. brasiliensis and ammonia by $R$. oryzae, as previously observed in $R$. oligosporus Saito when in nitrogen-rich culture media (Varga et al. 2007, Sparringa \& Owens 1999).

When compared to fungi from the same genera, A. brasiliensis activity occurs in a more acidic $\mathrm{pH}$ and higher temperature than most of the others. Gudi et al. (2013) described that the glucoamylase of $A$. niger shows an optimum $\mathrm{pH}$ in the range of $A$. brasiliensis (4.5-5.5) and temperature below $\left(65^{\circ} \mathrm{C}\right)$. A awamori, a species close to $A$. brasiliensis, has a better activity 
in higher $\mathrm{pH}$ (range 4.8/5.8) and in lower temperatures (range 40/42$48^{\circ} \mathrm{C}$ ) (Prakasham et al. 2007, Pestana \& Castilho 1985). A. fumigatus showed a similar optimum temperature (Silva \& Peralta 1998). The great temperature stability is also an interesting characteristic of the $A$. brasiliensis glucoamylase. The same enzyme from $A$. niger has an inferior stability (half-life of 45 minutes at $50^{\circ} \mathrm{C}$ ) like $A$. awamori ( $40 \%$ of residual activity after 30 minutes at $50^{\circ} \mathrm{C}$ ) (Gudi et al. 2013, Pestana \& Castilho 1985). A. fumigatus showed similar stability of temperature (Silva \& Peralta 1998). The $\mathrm{pH}$ stability results were similar to the $A$. niger glucoamylases and superior to the stability of $A$. awamori (Nakaz.) (range $\mathrm{pH}$ 6.0-9.0) (Gudi et al. 2013, Pestana \& Castilho 1985).

The $R$. oryzae strain isolated in this work produced glucoamylases with $\mathrm{pH}$ and temperature of activity with characteristics similar to the same species strain of Roch-chui \& Hang (1990). R. delemar has glucoamylases that act better in $\mathrm{pH}$ within the range of $R$. oryzae (4.5) and lower optimum temperature $\left(40^{\circ} \mathrm{C}\right)$ (Soccol et al. 1994). $R$. niveus has the activity $\mathrm{pH}$ in a higher range (4.5-6) and the same optimum temperature than $R$. oryzae (Saha \& Ueda 1983). The tolerance from thermal denaturation of the glucoamylase in the absence of the substrate was extreme low. The $\mathrm{pH}$ stability results were again like the strain in the work of Roch-chui \& Hang (1990). Rhizopus microsporus var. rhizopodiformis, a thermo-tolerant strain, showed lower stability of $\mathrm{pH}$ (approximately $80 \%$ of residual activity in the range of 2.5-7.5, after only 2 hours of incubation) (Peixoto et al. 2003).

Therefore, from environmental samples from the Brazilian Atlantic Forest, it was possible to isolate filamentous fungi strains that produced high amounts of amylases with distinct biochemical characteristics. These differences reflect upon the evolutionary history of $R$. oryzae, a basal filamentous fungus that alkalinizes the culture media during growth and secretes a less stable glucoamylase, with half-life of 12 minutes at $50^{\circ} \mathrm{C} ;$ A . brasiliensis, a derivative species that produces a highly stable, glucoamylase with half-life of 1 hour at $70^{\circ} \mathrm{C}$, and an acidic one, with great activity at $\mathrm{pH} 3.5$, so that it has interesting characteristics for future large-scale applications.

\section{Acknowledgements}

This work was supported by grants from Fundação de Amparo à Pesquisa do Estado de São Paulo (FAPESP), Conselho de Desenvolvimento Científico e Tecnológico (CNPq), National System for Research on Biodiversity (Sisbiota-Brazil, CNPq 563260/2010-6/FAPESP n ${ }^{\circ}$ 2010/52322-3). J.A.J. and M.L.T.M.P. are Research Fellows of CNPq. P.Z.A. was recipient FAPESP Fellowship (2013/01437-3) and M.G.P., C.C.C., P.R.H., L.S.Z., J.M.M. were recipient of CNPq and CAPES. We thank Ricardo Alarcon and Mariana Cereia for technical assistance and Abilio Borghi for language review.

\section{Authors Contributions}

Paula Zaghetto de Almeida, Maria de Lourdes Polizeli, Marita Gimenez Pereira: substantial contribution in the work conception and design.

Paula Zaghetto de Almeida, Maria de Lourdes Polizeli, Caio Cesar Carvalho, Paulo Ricardo Heinen, Luciana Sobrani Ziotti, Josana Maria Messias: contribution in data acquisition.

Paula Zaghetto de Almeida, Maria de Lourdes Polizeli, Marita Gimenez Pereira, Caio Cesar Carvalho, Paulo Ricardo Heinen, Luciana Sobrani Ziotti, Josana Maria Messias: contribution to the data analysis and interpretation.

Paula Zaghetto de Almeida, Maria de Lourdes Polizeli: contribution to the work writing.

Paula Zaghetto de Almeida, Maria de Lourdes Polizeli, Marita Gimenez Pereira, João Atílio Jorge: contribution to the critical review adding intellectual content.

\section{Conflict of Interests}

The authors declare no conflict of interests.

\section{References}

ADAMS, P. R. 1990. Mycelial amylase activities of thermophilic species of Rhizomucor, Humicola and Papulaspora. Mycopathologia 112: 35-37.

BALAJEE S.A., BADDLEY J.W., PETERSON S.W., NICKE D., VARGA J., BOEY A., LASS-FLÖRL C., FRISVAD J.C., SAMSON R.A. 2009. Aspergillus alabamensis, a new clinically relevant species in the section Terrei. Eukaryot. Cell. 8:713-722.

BALLESTEROS I., OLIVA J.M., NEGRO M.J., MANZANARES P. \& BALLESTEROS M. 2002. Enzymatic hydrolysis of steam exploded herbaceous agricultural waste (Brassica carinata) at different particle sizes. Process Biochem. 38:187-192.

BLACKWELL M. 2011. The Fungi: 1, 2, 3.. 5.1 million species? Am. J. Bot. 98 (3):426-438

CASTRILLO M.L., FONSECA M.I., BICH G.A., JERKE G. \& HORIANSKI MA. 2012. Taxonomy and phylogenetic analysis of Aspergillus section Nigri isolated from yerba mate in misiones (Argentina). J. Basic Appl. Genet. 23:19-27.

COSTA M.O., MOTTA C.M.S. \& MALOSSO E. 2012. Diversity of filamentous fungi in different systems of land use. Agroforest. Syst. 85:195-203.

COUTINHO P.M. \& REILLY P.J. 1997. Glucoamylase structural, functional and evolutionary relationships. Proteins: Struct. Funct. Genet. 29:334-347.

DHALI, R., DEY, A., CHATTOPADHYAY, A. N., SAHA, P., MUKHOPADHYAY, S. K., ROY, P., \& CHATTERJEE, S. 2016. Isolation, characterization and study of amylase activity of microorganisms from arctic soil sample. AOBR, 3:5-15.

DOMSCH K.H., GAMS W. \& ANDERSON T. 2007. Compendium of soil fungi. San Francisco: IHW-Verlag ed.

EDGAR R.C. 2004. MUSCLE: multiple sequence alignment with high accuracy and high throughput. Nucleic Acids Res. 32:1792-7.

GLASS N.L. \& DONALDSON G.C. 1995. Development of primer sets designed for use with the PCR to amplify conserved genes from filamentous ascomycetes. Appl. Environ. Microbiol. 61: 1323-1330.

GEISER D.M., DORNER J.W., HORN B.W., TAYLOR J.W. 2000. The phylogenetics of mycotoxin and sclerotium production in Aspergillus flavus and Aspergillus oryzae. Fungal Genet. Biol. 31:169-79.

GUDI S.K., CHANDRNSEKHAN G., RATHER G., CHAMDRA M.G.S., MANGAMURI U.K., PODHA S.E. \&, CHOI Y.L. 2013. Glucoamylase from a newly isolated Aspergillus niger FME: detergent-mediated production, purification, and characterization. J. Korean Soc. Appl. Biol. Chem. 56:427-433.

JOLY C.A., METZGER J.P. \& TABARELLI M. 2014. Experiences from the Brazilian Atlantic Forest: ecological findings and conservation initiatives. New Phytol. 204 (3):459-473.

KHANNA P., SUNDARI S.S \& KUMAR N.J. 1995. Production, isolation and partial purification of xylanase from an Aspergillus sp. World J. Microbiol. Biotechnol. 11:242-243.

KIRK P.M., CANNON P.F., MINTER D.W. \& STALPERS J.A. 2008. 10th ed Dictionary of the fungi. Wallingford: CABI Press.

LIOU G.Y., CHEN S.R., WEI Y.H., LEE F.L., FU H.M., YUAN G.F., \& STALPERS J.A. 2007. Polyphasic approach to the taxonomy of the Rhizopus stolonifer group. Fungal Biol. 111:196-203.

MAKI, C. S.; TEIXEIRA, F. F.; PAIVA, E. \& PACCOLAMEIRELLES, L. D 2001. Analyses of genetic variability in Lentinula edodes through mycelia responses to different abiotic conditions and RAPD molecular markers. Braz. J. Microbiol., 32(3):170-175.

MILLER G.L. Use of dinitrosalicylic acid reagent for determination o reducing sugars. 1959. Anal. Chem. 31:426-428.

MCILVAINE T.C. 1921. A buffer solution for colorimetric comparison. J. Biol. Chem. 49:183-186.

PEIXOTO S.C., JORGE J.A., TERENZI H.F. \& POLIZELI M.L.T.M. 2003. Rhizopus microsporus var. rhizopodiformis: a thermotolerant fungus with potential for production of thermostable amylases. Int. Microbiol. 6:269-273. 
PESTANA F. \& CASTILHO F.J. 1985. Glucoamylase production by Aspergillus awamori on rice flour medium and partial characterization of the enzyme. MIRCEN J. Appl. Microbiol. Biotechnol. 1:225-237.

PRAKASHAM R.S., SUBBA C.H.R., SREENIVAS R.R., SARMA P.N. 2007. Enhancement of acid amylase production by an isolated Aspergillus awamori. J. Appl. Microbiol. 102:204-211.

RIBEIRO M.C., METZGER J.P., MARTENSEN A.C., PONZONI F.J., HIROTA, M.M. 2009. The Brazilian Atlantic Forest: How much is left, and how is the remaining forest distributed? Implications for conservation. Biol. Cons. 142(6):1141-1153.

RIZZATTI A.C.S, JORGE J.A., RECHIA C.G.V \& POLIZELI M.L.T.M. 2001. Purification and properties of a thermostable extracellular $\beta$-D-xylosidase produced by thermotolerant $A$. phoenicis. J. Ind. Microbiol. Biotechnol. 26:156-160.

ROCH-CHUI Y. \& HANG Y.D. 1990. Amylolytic enzyme production by Rhizopus oryzae grown on agricultural commodities. World J. Microb. Biot. 6:15-18.

SAHA B.C., UEDA S. 1983. Raw starch adsorption, elution and digestion behavior of Rhizopus niveus. J. Ferm. Technol. 61:67-72.

SHI L.L., MORTIMER P.E., SLIK J.F., ZOU X.M., XU J., FENG W.T., \& QIAO, L. 2014. Variation in forest soil fungal diversity along a latitudinal gradient. Fungal Divers. 64(1): 305-315.

SCHOENLEIN-CRUSIUS I.H \& MILANEZ A.I. 1998. Fungos microscópicos da Mata Atlântica de Paranapiacaba, São Paulo, Brasil. Braz. J. Bot. 21:73-79.

SCHOENLEIN-CRUSIUS I.H., MILANEZ A.I., TRUFEM S.F., PIRESZOTTARELLI C.L., GRANDI R.A.P., SANTOS M.L., \& GIUSTRA, K.C. 2006. Microscopic fungi in the Atlantic Rainforest in Cubatão, São Paulo, Brazil. Braz. J. Microbiol. 37:267-275.

SILVA W.B. \& PERALTA R.M. 1998. Purification and characterization of a thermostable glucoamylase from Aspergillus fumigatus. Can. J. Microbiol. 44:493.497.

SOCCOL C.R., MARIN B., RAIMBAULT M. \& LEBEAULT J.M. 1994. Breeding and growth of Rhizopus in raw cassava by solid state fermentation. Appl. Microbiol. Biotechnol. 41:330-336.

SOUZA, P.M \& MAGALHÃES P.O. 2010 Application of microbial $\alpha$-amylase in industry - A review. Braz. J. Microbiol. 41:850-861.

SINGH, S., SINGH, S., BALI, V., SHARMA, L., \& MANGLA, J. 2014. Production of fungal amylases using cheap, readily available agriresidues, for potential application in textile industry. BioMed Res. Int. 2014:1-9.

SPARRINGA R.A. \& OWENS J.D. 1999. Causes of alkalization in tempe solid substrate fermentation. Enzyme Microb. Technol. 25:677-681.
TAJIMA F. \& NEI M. 1984. Estimation of evolutionary distance between nucleotide sequences. Mol. Biol. Evol. 1:269-285.

TAMURA K., PETERSON D., PETERSON N., STECHER G., NEI M. \& KUMAR S. 2013. MEGA6: molecular evolutionary genetics analysis version 6.0. Mol. Biol. Evol. 30:2725-2729.

TAUK TORNISIELO S.M., GARLIPP A., RUEGGER M., ATILLI D.S., \& MALAGUTTI M. 2005. Soilborne filamentous fungi in Brazil. J. Basic Microbiol. 45:72-85.

TEDERSOO L., BAHRAM M., PÕLME S., KÕLJALG U., YOROU N. S., WIJESUNDERA R., RUIZ L. V., VASCO-PALACIOS A. M., THU P. M., SUIJAA., SMITH M.E., SHARP C., SALUVEER E., SAITTAA., ROSAS M., RIIT T., RATKOWSKY D., PRITSCH K., PÕLDMAA K., PIEPENBRING M., PHOSRI C., PETERSON M., PARTS K., PÄRTEL K., OTSING E., NOUHRA E., NJOUONKOU A.J., NILSSON R. H., MORGADO L.N., MAYOR J., MAY T.W., MAJUAKIM L., LODGE D.J., LEE S.S., LARSSON K.H., KOHOUT P., HOSAKA K., HIIESALU I., HENKEL T.W., HAREND H., GUO L.D., GRESLEBIN A., GRELET G., GEML J., GATES G., DUNSTAN W., DUNK C., DRENKHAN R., DEARNALEY J, KESEL A., DANG T., CHEN X., BUEGGER F., BREARLEY F.Q., BONITO G., ANSLAN S., ABELL S., ABARENKOV K. 2014. Global diversity and geography of soil fungi. Science 346 (6213):1256688.

VAN DER MAAREL M.J.E.C., VAN DER VEEN B., UITDEHHAG J.C.M., LEEMHUIS H. \& DIJKHUIZEN L. 2002. Properties and applications of starch-converting enzymes of the $\alpha$-amylase family. J. Biotechnol. 94:137-155.

VARGA J., KOCSUBÉ S., TÓTH B. FRISVAD J.C., PERRONE G., SUSCA A., MEIJER M. \& SAMSON R.A. 2007. A brasiliensis sp. nov., a biseriate black A. species with worldwide distribution. Int. J. Syst. Evol. Micr. 57:1925 -1932.

VIELLE C. \& ZEIKUS G.J. 2001. Hyperthermophilic enzymes: sources, uses and molecular mechanisms for termostability. Microbiol. Mol. Biol. R. 65:1- 43.

VOGEL H.J. 1964. Distribution of lysine pathways among fungi: evolutionary implications. Am. Nat. 98:435-446.

WHITE T.J., LEE S. \& TAILOR S. 1990. Amplification and direct sequencing of fungal ribosomal RNA genes for phylogenetics in PCR protocols: a guide to methods and applications. California: Academic Press Inc. San Diego; pp 315-322.

Received: $23 / 02 / 2017$

Revised: 26/05/2017

Accepted: $14 / 07 / 2017$

Published online: 21/08/2017 